\begin{tabular}{|c|l|}
\hline Title & Of serendipities, success and failure and insider/outsider status in participant observation \\
\hline Author(s) & Klien, Susanne \\
\hline Citation & Studying Japan: Handbook of Research Designs, Fieldwork and Methods, ISBN:978-3-8487-5085-6 \\
\hline Issue Date & 2020-12 \\
\hline Doc URL & http:/hdl.handle.net/2115/83750 \\
\hline Type & bookchapter (author version) \\
\hline File Information & Klien_24.4.2019_rev.pdf \\
\hline
\end{tabular}

Instructions for use 


\section{Of serendipities, success and failure and insider/outsider status in participant observation}

Susanne Klien, Hokkaido University

"You are female, aren't you?" I will never forget the question by the local government representative I was talking to on the phone back in 2009 in order to inquire about a permission to conduct fieldwork during a renowned local Shinto mountain festival in Okinoshima, Shimane Prefecture. It turned out that I could not actively participate in the festivities as it was a sacred Shinto event, with women only taking part in backstage preparatory roles. I remember my initial frustration, thinking that this was a major setback for my research. In hindsight, however, I only found out that I was fortunate. My partner (who hardly spoke any Japanese but actively participated) ended up with black and blue knees and muscle aches all over as he had joined the team that did the 2-day-preparatory work for the festivities. I, on the other hand, accompanied the team throughout, but was not actively involved and focused on observing, gaining important insights in the process. This episode shows that what may be perceived as a setback may eventually turn out to be a merit. Similarly, Eriksen has observed that “...Even unsuccessful is rarely entirely unsuccessful, and it is often stressed that the notorious ability of anthropologists to make fools of themselves in the field [...] can actually be a methodological advantage." (Eriksen 2009, p. 54).

The above episode also highlights the broad range of roles that participant observation may entail. Being actively involved is usually perceived as a key feature of fieldwork; yet, external circumstances may limit the scope of participation. Evidently, being a member of the team preparing the festivities is bound to give you insights that cannot be obtained by being a mere observer. Spending extensive periods of time with the group one is researching, sweating and downing sake together with locals creates a level of visceral rapport that is beyond reach for armchair researchers. However, 'simply hanging out', lingering at the site may in fact give you a larger analytical sense of the site and its people. It may in fact yield valuable insights into how people relate to one another, communication patterns, power relations and other key features of social life. The next section is concerned with the concrete process of observation.

\section{HOW TO OBSERVE}

Few ethnographers would contest Eriksen's description of fieldwork as a "time-intensive enterprise." (Eriksen 2009, p. 49). After all, researchers spend months, if not years, at their sites. Compared to other research methods, fieldwork involves large amounts of 
individual time spent researching a relatively small sample of interviewees. Whereas this small sample is regularly criticized by sociologists and other researchers relying on quantitative methods, this constellation has afforded ethnographers the leeway of implementing in-depth observation of their chosen sites. Ethnography is an effective research tool that facilitates systemic observation which does not rely on first (or second) impressions, but combines the researchers' extensive observations with interviewees' narratives, often blending these multiple layers of meaning into an incisive analysis. Once you enter the field, many things that you observe as a researcher may strike you as odd. At this stage, I would say that the key to turning your fieldwork into a success is to sharpen your sense of your own view and its limitations - "seeing one's seeing," (jibun no mie wo miru) as Kato incisively puts it (2009, p. 51). Certain assumptions that we take for granted may not hold valid in the field; expanding your self-reflective skills is essential.

Malinowski famously pointed out that 'foreshadowed problems' should be a key feature (1922, p. 2), yet ethnographers are bound to encounter unanticipated occurrences, phenomena and events. From my own experience, it is these serendipities that often literally, open doors to new networks, interviewees and insights. I vividly remember standing on a square in Ishinomaki, Miyagi Prefecture, during lunch time, wondering where I could get a bite. Just then, three elderly local women appeared, opening a door to a place that looked like a private house. I seized this opportunity asking them whether that place was a restaurant, they nodded and asked me to join. This moment eventually resulted in me eating a large part of the ladies' lunch and befriending the restaurant owner, who became a key interlocutor and incidentally, my home stay host in later phases of my fieldwork. This episode indicates that during fieldwork, acting on the spot, behaving a tad beyond what is considered socially appropriate is often productive. It does not need to be emphasized that respecting the local community (or the group of your interlocutors) should be accorded the highest priority at all times during fieldwork. In order to seize such moments effectively, however, we need to sharpen our sense of visceral instinct, something we have often unlearned in academic contexts.

I generally recommend lingering around wider rather than smaller groups of people especially in the initial stages of your fieldwork, but starting with a clearly bounded group may be helpful. After some time spent in the field, more specific sets of questions and issues will emerge that strike your research interest so that you can narrow down your themes. For example, during my ethnographic research into disaster volunteers after the Great East Japan Earthquake in March 2011, I started by signing up as a disaster volunteer myself. First, I mostly spent time with other disaster volunteers, but later expanded my fieldwork to disaster volunteer coordinators, local government representatives, local 
residents supporting disaster volunteers and local residents who had no personal relations with volunteers. Engaging with diverse groups of interlocutors gave me a more comprehensive view of the phenomenon I was researching, i.e. the motives of disaster volunteers to embark on altruistic work. In a similar vein, Roth observes about his fieldwork among Japanese and Japanese Brazilian workers in Japan that "By talking to as many of these workers, bureaucrats, and other intermediary cultural brokers as I could early on in my research, I was able to get my bearings in the field site more quickly than I could have on my own." (Roth 2003, p. 343-4).

\section{CHALLENGES DURING PREPARATION AND IMPLEMENTATION}

As emphasized by numerous other researchers, the way ethnographers enter the field considerably shapes the research to come. The position of the person introducing the researcher to others in the field, the 'gatekeeper', must not be underestimated. For example, during my recent fieldwork with hip hop practitioners in Hokkaido, northern Japan, one of my key interlocutors and gatekeeper was a local male who had previously been a DJ in the club that was my key field site. On the one hand, the fact that he was a veteran practitioner gave me access to events and parties that were only open to members of the scene as such events were disseminated by word-of-mouth. However, at the same time, the fact that I attended many events together with him placed me in a special segment of the scene. In other words, I recommend making informed choices when choosing gatekeepers and keeping in mind that there are always downsides, regardless of what choice you make. I believe that we can minimize such downsides by behaving in an accessible (i.e. open and amicable) manner when hanging out and encountering members of the site that we are researching although we have to accept downsides as facts of life. Related to this, from my own ethnographic experience I would like to argue that the most insightful fieldwork results from a balance between the researcher's insider and outsider status. As Reader has previously argued, "By contrast, my outsider position worked to my advantage, as my Japanese academic colleague recognized, I had been able to make a suggestion and get away with what could have been an indecorous request." (Reader 2003, p. 103). Dales and Yamamoto similarly note that some of their interviewees "would not have felt comfortable sharing certain stories with us had we been Japanese." (2019, p. 242) Evidently, being an outsider does entail numerous advantages that we need to work with in order to obtain incisive results as fieldworkers. During my fieldwork into the hip hop scene, I aimed for a balance between inconspicuousness and out-of-the-box questions. My gender turned out to be more of a merit than a disadvantage as male practitioners seemed eager to share their thoughts with a female outsider unrelated to the 
scene - something I had not anticipated at the beginning of my fieldwork.

\section{GENERAL RECOMMENDATIONS}

To sum up, I will provide three pieces of advice for a smooth fieldwork experience. First, as previously indicated by Hendry (2003, p. 69), seizing chance encounters is key to successful ethnographic research. I encourage all fieldworkers, especially neophytes, to overcome inhibitions to talk to strangers. As outlined in my episode with the senior ladies in Ishinomaki, I would not have met my long-term host and gatekeeper there, had I not followed them on the spur of the moment.

Second, verbal statements by interlocutors need to be taken with a grain of salt. Freeman emphasizes the importance of "the ways in which they spoke, the timbre and lilt of their voices, the intensity of their expression, and the look in their eyes." (2014, p. 135) Make sure that you do not focus too much on oral narratives, but also observe people's facial expression and body language. I remember a group interview in northeast Japan after the 2011 Great East Japan Earthquake that I was conducting with two colleagues, one of whom did not speak a word of Japanese. Sharing our impressions after the interview was a real eye-opener since the colleague with no Japanese language skills was forced to focus on facial expression and body language.

Related to that, I highly recommend talking to key interviewees several times and arranging meetings with them outside of the field, if possible. The field shapes interlocutors' statements to a larger extent than we assume, especially in rural communities. During my fieldwork with lifestyle migrants in Tokushima Prefecture in 2017, a female settler described her life in her newly chosen community in overly positive terms, although she did refer to some challenges. Six months later we met again in Hokkaido. It turned out that she had decided to leave the community soon after our meeting as she generally disliked rural life. In a small rural town, she felt that she could not talk freely about her real thoughts. In other words, talking to interlocutors outside the field may provide more nuanced insights.

Last but not least, listening well is a skill that is usually taken for granted, but the key to gaining in-depth insights during fieldwork.

\section{REFERENCES}

Dales, Laura/Beverly Anne Yamamoto (2019): Relating to 'Unconventional' Women. In: Alexy, Allison/Cook Emma (2018) (eds.): Intimate Japan: Ethnographies of Closeness and Conflict. Honolulu: University of Hawaii Press, pp. 241-2.

Eriksen, Thomas Hylland (2009): What is Anthropology. London/New York: Pluto Press. 
Freeman, Carla (2014): Entrepreneurial Selves: Neoliberal Respectability and the Making of a Caribbean Middle Class. Durham and London: Duke University Press.

Hendry, Joy (2003): "From Scrambled Messages to an Impromptu Dip: Serendipity in Finding a Field Location.” In: Bestor, Ted/Steinhoff, Pat/Bestor, Victoria (eds.): Doing Fieldwork in Japan. Honolulu: University of Hawaii Press, pp. 55-70.

Kato, Fumitoshi (2009): Kyanpuron: Atarashii fieldwork [Camp theory: New fieldwork]. Tokyo: Keio University Press.

Klien, Susanne (2016): "Reinventing Ishinomaki, reinventing Japan? Evolving creative networks, alternative lifestyles and the search for quality in life in post-growth Japan", Japanese Studies, Vol. 36, Issue 1, Japanese Studies Association of Australia, pp. 39-60. Klien, Susanne (2016): "Shinto Ritual Practice in Miyagi Prefecture after the Great East Japan Earthquake: The Case of the Ogatsu Hoin Kagura", Asian Ethnology, Nanzan Institute for Religion and Culture, Vol. 75: 2, pp. 359-376.

Malinowski, Bronislaw (1922): Argonauts of the Western Pacific. London: Routledge \& Kegan.

O'Reilly, Karen (2009): Key Concepts in Ethnography. Los Angeles, London, New Delhi, Singapore, Washington DC.

Reader, Ian (2003): Chance, Fate and Undisciplined Meanderings: A Pilgrimage through the Fieldwork Maze. In: Bestor, Ted/Steinhoff, Pat/Bestor, Victoria (eds.): Doing Fieldwork in Japan. Honolulu: University of Hawaii Press, pp. 89-105.

Roth, Joshua Hotaka (2003): Responsibility and the Limits of Identification: Fieldwork among Japanese and Japanese Brazilian workers in Japan. In: Bestor, Ted/Steinhoff, Pat/ Bestor, Victoria (eds.): Doing Fieldwork in Japan. Honolulu: University of Hawaii Press, pp. 335-51.

5 keywords for index:

Serendipity, insider/outsider status, non-verbal expressions of interviewees, failure and success in fieldwork, gatekeeper, informed choices

Further readings:

Powdermaker, Hortense (1966): Stranger and Friend: The Way of An Anthropologist. New York, London: Norton \& Company.

Sato, Tomohisa (2013): Fieldwork 2.0: Gendai sekai wo fieldwork [Fieldwork 2.0: Doing fieldwork in the contemporary world]. Tokyo: Kyoto Bunkyo Daigaku Bunkajinruigaku Booklet No. 8. 